\title{
PREGNANCY AFTER LIVER TRANSPLANTATION
}

\section{Salih SERIN, Gurkan KIRAN, Hakan KIRAN, Ayhan COSKUN, Deniz Cemgil ARIKAN}

Department of Gynecology and Obstetrics, Sutcu Imam University, Medicine Faculty, Kahramanmaraş, Turkey

\section{SUMMARY}

The number of solid organ transplantations in reproductive-age women increases each year. Favourable pregnancy outcomes have been obtained in women underwent liver transplantation following diagnosis of liver insufficiency. Patients who become pregnant after liver transplantation are considered as high risk pregnancy. For achieve optimal maternal and fetal outcomes; these patients should be monitored in a multidisciplinary approach. In this case report; pregnancy follow-up and outcome of a case with a history of liver transplantation and two live births after transplantation are discussed.

Key words: alfa 1 antitripsin deficiency, liver transplantation, pregnancy

Journal of Turkish Society of Obstetrics and Gynecology, (J Turk Soc Obstet Gynecol), 2013; Vol: 10, Issue: 3, Pages: 201- 5

\section{KARACIĞER NAKLİ SONRASI GEBELIKK}

\section{ÖZET}

Reprodüktif çăgdaki bayanlarda solid organ transplantasyonu her geçen gün artmaktadır. Kronik karaciğer yetmezliği nedeni ile takip edilen birçok hastada başarılı organ transplantasyonu sonrasında iyi gebelik sonuç ları elde edilmiştir. Karaciğer transplantasyonu sonrasında gebe kalan hastalar riskli gebelik olarak değerlendirilmektedir. Optimal maternal ve fetal sonuçların elde edilebilmesi için bu hastalar multidisipliner bir yaklaşımla izlenmelidir. Bu olgu sunumunda daha önce karaciğer transplantasyonu yapılmış ve transplantasyon sonrasında 2 canlı doğum yapan hastamızın gebelik takibi ve sonuçları tartışılmıştır.

Anahtar kelimeler: alfa 1 antitripsin eksikliği, gebelik, karaciğer nakli

Türk Jinekoloji ve Obstetrik Derneği Dergisi, (J Turk Soc Obstet Gynecol), 2013; Cilt: 10, Sayl: 3, Sayfa: $201-5$

Address for Correspondence: Dr. Salih Serin. Sütçü İmam Üniveristesi Tıp Fakültesi, Kadın Hastalıklanı ve Doğum Anabilim Dalı, Kahramanmaraş, Türkiye Phone: + 90 (0533) 9596644

e-mail: salih-serin@hotmail.com

Received: 18 July 2012, revised: 04 March 2013, accepted: 16 April 2013, online publication: 16 April 2013 


\section{INTRODUCTION}

Reproductive problems and irregular menstruation may be observed in approximately one half of female patients suffering from advanced liver diseases. These problems can be eliminated in $97 \%$ of the patients after a successful liver transplantation ${ }^{(1-4)}$. Normal menstrual cycles are seen in the patients within 8 months after the transplantation ${ }^{(2-5)}$.

First pregnancy in patient after solid organ transplantation was recorded in 1958, whereas first pregnancy in patient after liver transplantation was reported in 1978(6-8). Over 1400 pregnancies after transplantation have been recorded so far ${ }^{(9)}$.

\section{CASE}

In the history of a 20 year-old patient, it has been stated that she had alfa-1 antitrypsin deficiency diagnosed when she was 6 years old. When the patient was 16 years old, liver transplantation from a living being (her mother) was performed for the patient who had chronic liver failure observed in her follow-ups.

The patient applied to our clinic for the first time with the information of 8-week pregnancy and with the complaint of vaginal spotting two years ago. The situation of the patient getting immunosuppressive therapy (Tacrolimus-Prograph $2 \times 2$ ) at that moment was consulted to the health center where the transplantation was performed. As a result of the consultation, the patient was informed about the fact that the first year after liver transplantation would be risky for pregnancy and that it would be preferable to get pregnant in the following years in this kind of situations. Having accepted all these risks, the patient preferred the continuation of pregnancy; however, dilation/curettage was performed after the diagnosis of missed abortion in the follow-ups in the $11^{\text {th }}$ week of the pregnancy.

The pregnancy follow-ups of the patient who applied again to the clinic with the diagnosis of 12-week and 2-day pregnancy last year were monitored in the polyclinics of Gastroenterology and Obstetrics. In the double test, no risk was detected at the level where invasive procedure would be seen necessary. Anatomy ultrasound scan was used in 22nd+ week in the second trimester; fetal anomaly was not detected. Minimal ventricular septal defect (VSD) was found in the fetal echocardiography examination. Betametazone (Celestone 2x2 amp IM) was administered and tocolytics were given to the patient who applied to the hospital with the complaint of twinging in the 32nd week of pregnancy and who was admitted to the hospital after the diagnosis of preterm labor. Minimal elevation in the liver function tests was detected through biochemical examinations. With the recommendation of the health center where the transplantation was performed, the patient was sent to the aforesaid institution and caesarean section procedures were applied to the patient in that hospital in $34^{\text {th }}$ week of pregnancy. It was found that neither the mother nor the newborn had problems in the postpartum followups.

Three months ago, the patient was applied to our clinic with the information of 33-week and 2 -day pregnancy and with the complaint of twinging in her third pregnancy. Preterm labor was diagnosed in the examinations; as a result, she was admitted to the hospital and was monitored. While AST was measured as $109 \mathrm{U} / \mathrm{L}$, ALT as $193 \mathrm{U} / \mathrm{L}$, and total bilirubin as 2.1 $\mathrm{mg} / \mathrm{dL}$, the values of albumin, hemogram and coagulation were found normal. Caesarean procedures were applied to the patient in the $37^{\text {th }}$ week of pregnancy. In the follow-ups carried out in the 6th postpartum week, it was seen that the liver function tests turned out to be normal.

\section{DISCUSSION}

Pregnancy after organ transplantation should be evaluated in terms of the impacts of the pregnancy on the organ transplanted and on other systems as well as with the regards to maternal and fetal outcomes $(10,11)$.

Patients who are willing to get pregnant after solid organ transplantation should be monitored via multidisciplinary approach. These patients should be informed about which immunosuppressive agent will be administered during pregnancy and also about the subjects such as the period between pregnancy and transplantation; cervical cytology tests, infection screening (CMV, urinary culture), and liver and kidney function tests should be carried out. A period in which close follow-up will be necessary is foreseen for the patients who plan to get pregnant after transplantation. 
In the pregnancies after liver transplantation, when evaluated in terms of obstetric complications, hypertension, preeclampsia, caesarean section, intrauterine growth retardation, diabetes mellitus, anemia, infection and preterm delivery are observed more often than in the normal pregnant population $(13,14)$.

In the study carried out by Scantlebury and colleagues (15), 55\% of prematurity was observed in 20 patients who got pregnant after liver transplantation. According to the study of Ville and colleagues ${ }^{(16)}$, low birth weight was seen in only one patient whereas preterm delivery was not found in any of 11 live births. In this subject, the average of pregnancy weeks in these patients is given as 37 , and the average of birth weight is calculated as 2705 grams in the registers of National Transplant Pregnancy Registry (NTPR) ${ }^{(17)}$.

The rate of cesarean section is higher in these patients than in the normal population. In two minor studies, this rate is given as $63 \%$ and $36 \%$.

In the meta analysis made by Neha and colleagues, the rates of live birth, abortus and stillbirth are given respectively as $76.9 \%, 6.2 \%$ and $0.9 \%$ in 306 cases. In the publication within the scope of which it has been stated that ectopic pregnancy was seen in two patients, the rate of cesarean section is given as $44.6 \%$ in pregnant patients who were not in the term whereas the rate of preterm delivery is reported as $39.4 \%$.

Another possible problem that may occur in the pregnancies after transplantation is fetal anomalies which may arise secondary to the immunosuppressive agents used. The immunosuppressive agents most commonly applied after liver transplantation are corticosteroids, cyclosporine A, tacrolimus, Mycophenolate mofetil (MMF), and azathioprine; the categories of these agents in FDA guidance are respectively B, C, C, D and D. $\mathrm{MMF}$ and azathioprine are not generally preferred during pregnancy.

Armenti and colleagues(18) have found multiple anomalies in 2 patients, pyloric stenosis in one patient, total anomalous pulmonary venous return in another patient and hypospadias in another in the study that they carried out for pregnant patients under the age of 21. Jain and colleagues have found, in their study(19), tracheoesophageal fistula and heart valve diseases in one newborn; non-functional unilateral kidney cyst and accessory spleen in another.

Naggy and colleagues(13) have reported small membranous VSD in the babies of two mothers out of three who use tacrolimus, whereas they have observed hydrocele in the third one.

The researches emphasize that maternal-fetal toxicity is dose-dependent. Fetal echocardiogram is suggested to be applied with regards to cardiomyopathy in 20th22 nd week of pregnancy to the babies of the mothers taking tacrolimus $(20,21)$.

Another important issue for these pregnant patients is the ideal duration between the operation and pregnancy. Armenti and colleagues ${ }^{(18)}$ have emphasized that the abovementioned duration should be more than two years for better maternal and fetal outcomes in pregnancies after transplantation. Christopher and colleagues ${ }^{(22)}$ have stated that the probability of prematurity, low birth weight and acute rejection is considerably high in the pregnancies reported within the first year after transplantation. Malatesta and colleagues ${ }^{(23)}$ have expressed that the longer is the period between transplantation and pregnancy, the lesser will be the possibility of pregnancy complications. In general, numerous health centers suggest the retardation of pregnancy for one year after transplantation. This suggestion is supported by NTPR and it is underlined that the number of live births will increase while the number of organ rejection will decrease with the application of this method(24). At that point, it should be taken into consideration that in case of pregnancies in the early periods of transplantation, the infections such as CMV will develop more frequently depending upon the utilization of immunosuppressive agents in high doses and it should be remembered that these conditions will affect negatively the outcomes of pregnancy ${ }^{(25)}$.

In one of two studies which put emphasis on the importance of maternal age for the success of pregnancies after transplantation, Little and colleagues have stressed that the rate of live births after liver transplantation is inversely proportional to the maternal age. In the second study, Armenti and colleagues ${ }^{(18)}$ have expressed that the rate of successful pregnancies is $75 \%$ for the patients having experienced transplantation and under the age of 21.

Barrier methods and intra uterine devices are generally preferable for contraception within the period after transplantation; the utilization of oral contraceptives is not advised because of their possible negative impacts on liver ${ }^{8,26)}$.

Maternal systemic response may be in question as a 
result of the pregnancy or the drugs used after transplantation. Hypertension and preeclampsia are observed more frequently in these pregnancies than in normal population ${ }^{(15,27)}$. This situation may be derived from the vasoconstrictive impacts of cyclosporine A and tacrolimus ${ }^{(28)}$. The rate of preeclampsia is given as $21.9 \%$ in the study of Nahe and colleagues. Nagy and colleagues ${ }^{(13)}$ have stated that maternal renal damages are seen more often in cyclosporine A group when cyclosporine A and tacrolimus are compared. According to Christopher and colleagues ${ }^{(22)}$, there is not a significant difference between cyclosporine A and tacrolimus in terms of obstetric complication risks. As seen in NTPR data, hypertension and preeclampsia develop more frequently in the patients taking tacrolimus when compared with the patients taking cyclosporine A.

According to NTPR data, the rate of rejection after liver transplantation is about $8 \%(17)$. Vimala and colleagues have determined in their study that the rate of rejection is $33 \%$ within the first year after transplantation; this rate is given as $14 \%$ in the pregnancies seen after this period. Armenti and colleagues have expressed that acute rejection and tissue rejection may differentiate during pregnancy and within two years pursuant to this process according to the agents used. The loss of organ is observed during pregnancy in $5 \%$ of 57 patients having transplantation under the age of 21 while this rate is confirmed as $11 \%$ within the following two years ${ }^{(18)}$.

\section{CONCLUSION}

The follow-up of pregnancy for a patient to whom liver transplantation was applied is an important responsibility for the physician carrying out the followups. However, nowadays, the information and experiences in this field have increased considerably; therefore the rate of live birth after transplantation makes progress. In the light of this information, the desire of patients for getting pregnant should be appreciated and they should be informed about the fact that successful outcomes may be achieved with the help of close follow-ups. These cases, which should be remembered to take part in highly risky pregnancy category, should be monitored closely against possible pregnancy complications.

\section{REFERENCES}

1. Jabiry-Zieniewicz Z, Cyganek A, Luterek K, Bobrowska K, Kamifski P, Ziólkowski J, Zieniewicz K, Krawczyk M. Pregnancy and delivery after liver transplantation. Transplant Proc. 2005 Mar; 37(2): 1197- 200.

2. Heneghan MA. Pregnancy and the liver. In: Howdle PD, ed. Comprehensive Clinical Hepatology. 1st ed. London: Mosby, 2000; 3: 1- 3. 1 .

3. Cundy TF, O'Grady JG, Williams R. Recovery of menstruation and pregnancy after liver transplantation. Gut. 1990 Mar; 31(3): 337- 8 .

4. Mass K, Quint EH, Punch MR, Merion RM. Gynecological and reproductive function after liver transplantation. Transplantation. 1996 Aug 27; 62(4): 476- 9.

5. Brown KA, Lucey MR. Liver transplantation restores female reproductive endocrine function. Hepatology. 1991 Jun; 13(6): 1255- 7 .

6. Yildirim Y, Uslu A. Pregnancy in patients with previous successful renal transplantation. Int J Gynaecol Obstet. 2005 Sep; 90(3): 198- 202.

7. Casele HL, Laifer SA. Pregnancy after liver transplantation. Semin Perinatol. 1998 Apr; 22(2): 149- 55.

8. Laifer SA, Guido RS. Reproductive function and outcome of pregnancy after liver transplantation in women. Mayo Clin Proc. 1995 Apr; 70(4): 388- 94.

9. McKay DB, Josephson MA. Pregnancy in recipients of solid organs--effects on mother and child. N Engl J Med. 2006 Mar 23; 354(12): 1281- 93

10. Davison JM. Dialysis, transplantation, and pregnancy. Am J Kidney Dis. 1991 Feb; 17(2): 127- 32.

11. Armenti VT, Ahlswede KM, Ahlswede BA, Jarrell BE, Moritz MJ, Burke JF. National transplantation Pregnancy Registry-outcomes of 154 pregnancies in cyclosporine-treated female kidney transplant recipients. Transplantation. 1994 Feb 27; 57(4): 502- 6 .

12. Grow DR, Simon NV, Liss J, Delp WT. Twin pregnancy after orthotopic liver transplantation, with exacerbation of chronic graft rejection. Am J Perinatol. 1991 Mar; 8(2): 135- 8.

13. Nagy S, Bush MC, Berkowitz R, Fishbein TM, Gomez-Lobo V. Pregnancy outcome in liver transplant recipients. Obstet Gynecol. 2003 Jul; 102(1): 121- 8.

14. Ville Y, Fernandez H, Samuel D, Bismuth H, Frydman R. Pregnancy in liver transplant recipients: course and outcome in 19 cases. Am J Obstet Gynecol. 1993 Mar; 168(3 Pt 1): 896- 902 .

15. Scantlebury V, Gordon R, Tzakis A, Koneru B, Bowman J, Mazzaferro V, Stevenson WC, Todo S, Iwatsuki S, Starzl TE. 
Childbearing after liver transplantation. Transplantation. 1990 Feb; 49(2): 317- 21.

16. Ville Y, Fernandez H, Samuel D, Bismuth H, Frydman R. Pregnancy in liver transplant recipients: course and outcome in 19 cases. Am J Obstet Gynecol. 1993 Mar; 168(3 Pt 1): 896- 902.

17. Armenti VT, Radomski JS, Moritz MJ, Gaughan WJ, Hecker WP, Lavelanet A, McGrory CH, Coscia LA. Report from the National Transplantation Pregnancy Registry (NTPR): outcomes of pregnancy after transplantation. Clin Transpl. 2004: 103- 14 .

18. Coscia LA, Constantinescu S, Moritz MJ, Frank A, Ramirez CB, Maley WL, Doria C, McGrory CH, Armenti VT. Report from the National Transplantation Pregnancy Registry (NTPR): outcomes of pregnancy after transplantation. Clin Transpl. 2009: 103- 22 .

19. Jain AB, Reyes J, Marcos A, Mazariegos G, Eghtesad B, Fontes PA, Cacciarelli TV, Marsh JW, de Vera ME, Rafail A, Starzl TE, Fung JJ. Pregnancy after liver transplantation with tacrolimus immunosuppression: a single center's experience update at 13 years. Transplantation. 2003 Sep 15; 76(5): $827-32$

20. Armenti VT, Moritz MJ, Davison JM. Drug safety issues in pregnancy following transplantation and immunosuppression: effects and outcomes. Drug Saf. 1998 Sep; 19(3): 219- 32.

21. Vyas S, Kumar A, Piecuch S, Hidalgo G, Singh A, Anderson V, Markell MS, Baqi N. Outcome of twin pregnancy in a renal transplant recipient treated with tacrolimus. Transplantation. 1999 Feb 15; 67(3): 490- 2.

22. Christopher V, Al-Chalabi T, Richardson PD, Muiesan P, Rela M, Heaton ND, O'Grady JG, Heneghan MA. Pregnancy outcome after liver transplantation: a single-center experience of 71 pregnancies in 45 recipients. Liver Transpl. 2006 Jul; 12(7): 1138- 43 .

23. Dei Malatesta MF, Rossi M, Rocca B, Iappelli M, Giorno MP, Berloco P, Cortesini R. Pregnancy after liver transplantation: report of 8 new cases and review of the literature. Transpl Immunol. 2006 Apr; 15(4): 297- 302.

24. Armenti VT, Herrine SK, Radomski JS, Moritz MJ. Pregnancy after liver transplantation. Liver Transpl. 2000 Nov; 6(6): 671- 85 .

25. Heneghan MA, Sylvestre PB. Cholestatic diseases of liver transplantation. Semin Gastrointest Dis. 2001 Apr; 12(2): 133- 47.

26. Shlay JC, Mayhugh B, Foster M, Maravi ME, Barón AE, Douglas JM Jr. Initiating contraception in sexually transmitted disease clinic setting: a randomized trial. Am J Obstet Gynecol. 2003 Aug; 189(2): 473- 81.

27. Ville Y, Fernandez H, Samuel D, Bismuth H, Frydman R. Pregnancy after hepatic transplantation. 17 pregnancies. J Gynecol Obstet Biol Reprod (Paris). 1992; 21(6): 691- 6.

28. Textor SC, Taler SJ, Canzanello VJ, Schwartz L, Augustine JE. Posttransplantation hypertension related to calcineurin inhibitors. Liver Transpl. 2000 Sep; 6(5): 521- 30. 